\title{
Comparison of The Fiber Characteristics of the Some Cotton Varieties Ginned by Using Sawgin and Rollergin
}

\author{
Sevtap Kartal ${ }^{1, a}$, Lale Efe ${ }^{2, b, *}$ \\ ${ }^{I}$ Field Crops Department, Science Institute, Kahramanmaraş Sütçü Imam University, 46050 Kahramanmaraş, Turkey \\ ${ }^{2}$ Field Crops Department, Faculty of Agriculture, Kahramanmaraş Sütçü Imam University, 46050 Kahramanmaraş, Turkey
}

*Corresponding author

\begin{tabular}{|c|c|}
\hline ARTICLE INFO & ABSTRACT \\
\hline $\begin{array}{l}\text { Keywords: } \\
\text { Cotton } \\
\text { Gossypium hirsutum } \mathrm{L} \\
\text { Rollergin } \\
\text { Sawgin } \\
\text { Fiber characteristics }\end{array}$ & 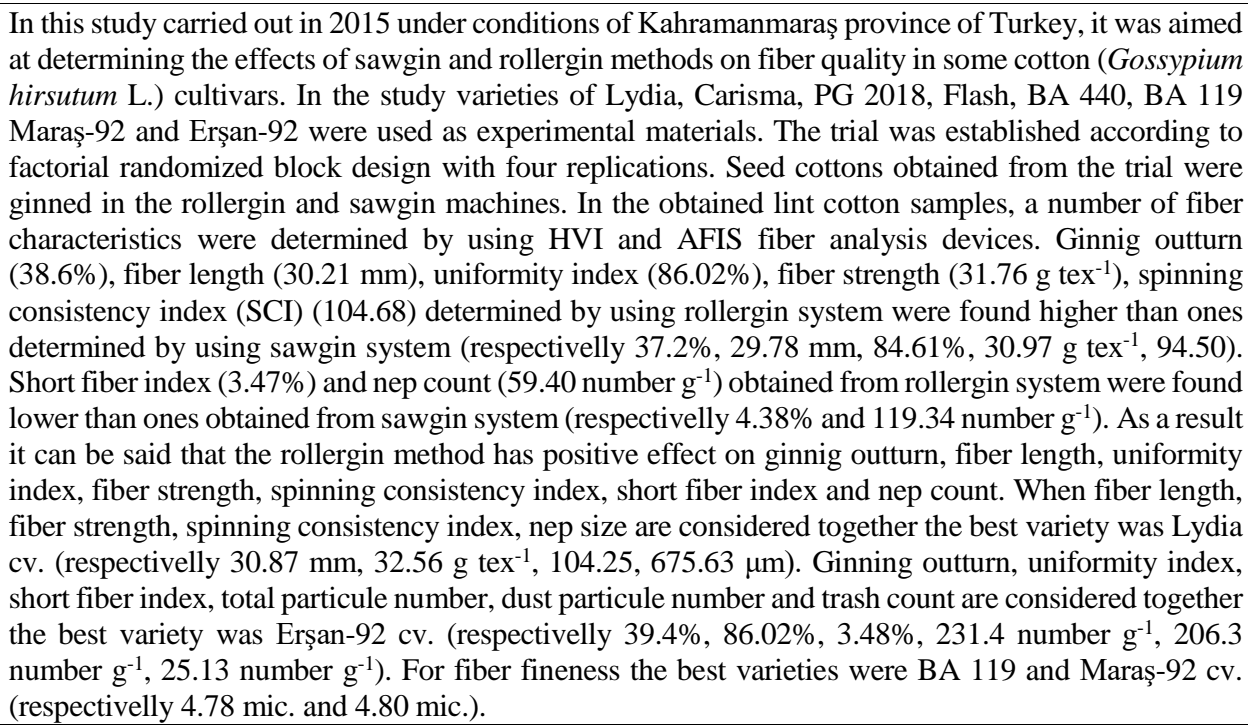 \\
\hline
\end{tabular}

sewtap777@gmail.com(1) https://orcid.org/0000-0001-6411-7513

b@efe@ksu.edu.tr

https://orcid.org/0000-0002-7077-5552

(c) (1) (8) This work is licensed under Creative Commons Attribution 4.0 International License

\section{Introduction}

When quality lint is said it has been understanding fibers that are superior in terms of mainly such as technological properties of length, fineness, strength, elongation, brightness and matured, cleaned from trash and having higher ability of spinning consistency index. Cotton lint which is natural agricultural product can be have considerably different properties from year to year, from field to field, from bale to bale even from fiber to fiber (Tümer, 2010).

It is necessary to be best known that physical and chemical values of lint cotton such as fiber fineness, fiber length, fiber strength, short fiber index, nep count, trash count for preparing of production program of yarn mills and lint trading (Anonymous, 2006). Technological development of ginning systems and yarn machines was effective to spreading of cotton cultivation. (Oğlakc1, 2012).
Ginning usually separates cotton seeds from fibers and prepares fibers to yarn production. In Turkey rollergin and sawgin have been used widely. There has been 580 ginninglinter-bale pressing mills in 2013-2014 cotton growing season. $97.6 \%$ of ginning mills consist of rollergins, $0.22 \%$ of ones consist of sawgins and $1.92 \%$ of ones consist of lintergins (Özel, 2015). In Turkey rollergin system has been used at ginning mills extensively. But ginning mills having sawgin system there are limited number because of higher establishment costs, labour costs and energy charges. Although both methods have advantages and disadvantages according to one another seed cotton cleaning before ginning and lint cleaning after ginning gained more important due to increasing of trash content depending on becoming prevalent of machine harvest. Therefore, studies on determination of effects of ginning systems on lint quality are needed. In this study carried out in 2015 under conditions of Kahramanmaraş province of Turkey, 
it was aimed at determining the effects of sawgin and rollergin methods on fiber quality in eight cotton (Gossypium hirsutum L.) cultivars by using HVI (High Volume Instruments) and AFIS (Advanced Fiber Information Systems).

\section{Materials and Methods}

\section{Materials}

\section{Plant Materials}

In this study Lydia, Carisma, PG 2018, Flash, BA 440, BA 119 cotton cultivars (Gossypium hirsutum L.) provided from ProGen Seed Ltd. and Maraş-92 and Erşan-92 cultivars (G. hirsutum L.) provided from Directorate of East Mediterranean Transitional Zone Agricultural Research Institute were used as materials.

\section{Experiment Field and Soil Properties}

Kahramanmaras province in which was carried out the field experiment is located between $37^{\circ} 11^{\prime}$ and $38^{\circ} 36^{\prime}$ North latitudes and $36^{\circ} 15^{\prime}$ and $37^{\circ} 42^{\prime}$ east longitudes. The study was carried out in 2015 in cotton growing season at the experimental field of Directorate of East Mediterranean Transitional Zone Agricultural Research Institute. According to soil analysis lime ratio of the experimental soil was high. There was not salt problem in the experiment field. The experiment field was slightly alkaline and inadequate for organic matter, sufficient for potassium and it had high magnesium.

Experiment Location and Climate Type

Kahramanmaras province is located at East Mediterranean Region of Turkey and it has typical Mediterranean climate which is summers are hot and dry, winters are warm and rainy.

\section{Methods}

\section{Experiment Design}

The study was carried out according to factorial randomized block design with four replications.

\section{Soil Preparation and Sowing}

Soil of experiment field was plowed by using plough $25 \mathrm{~cm}$ depth in autumn. After winter prior to sowing the soil was cultivated with cultivator and rotatiller when soil moisture is properly taking into consideration of weeds. Then soil got ready sowing with wooden harrow. The seeds of investigated cultivars were sown by using planter according to experimental design on 22 May 2015 to four row's plots of $5 \mathrm{~m}$ length at $70 \mathrm{~cm}$ row spacing. But because the plants were damaged by hail after germination, sowing was repeated on 10 June 2015.

\section{Cultural Practices}

After germination when plants had 4-5 leaves, they were thinned to $20 \mathrm{~cm}$ in rows. During the growing season plants were hoed 3 times and harrowed 3 times to protect growing cotton seedlings from foreigner plants, to prevent evaporation of soil water, to provide development and deepening of roots of seedlings. Plants were furrow irrigated 7 times until 15 days before opening of the first bolls taking into consideration development of the plants and soil water. Half one's nitrogen was applied in presowing period, half one's it was applied in presquaring period prior to first irrigation by using a fertilizer spreader in inter-rows as total $20 \mathrm{kgda}^{-1}$. Phosphorus was applied in presowing period at a rate of $6 \mathrm{kgda}^{-1} \mathrm{P}_{2} \mathrm{O}_{5}$. Composed fertilizer (20:20:0) and 46\% of Urea were used in presowing and surface fertilization respectively. It was combat once against Empoasca decipiens Paoli (Homoptera: Cicadellidae) with recommended doses on 5 August 2015.

Sample Picking

Before harvesting when 50-60\% of bolls opened 30 boll's samples were picked from middle two row's plant's bolls in same position randomly.

Harvesting

Seed cotton were harvested on 15 October and 5 November 2015 as twice from middle two rows of plots.

Properties Investigated

Ginning Outturn (\%)

Seed cotton samples taken from each plot were splited two parts and they were ginned with rollergin and sawgin. Then the seeds and lints were weighed separately and calculated by using formula as follows.

\section{Ginning outturn $(\%)=\operatorname{Lint}(\mathrm{g}) / \operatorname{Lint}(\mathrm{g})+\operatorname{Seed}(\mathrm{g}) \times 100$}

Lint properties of the samples were determined by using HVI (High Volume Instruments) and AFIS (Advanced Fiber Systems).

\section{Machines and Devices Used \\ Rollergin Machine}

Rollergin machines have a simple processing principles and they have been used in Turkey predominantly. The seed cotton samples were ginned by using rollergin machine at laboratory of Field Crops Department of Agricultural Faculty of Kahramanmaraş Sütçü İmam University in Kahramanmaras.

Sawgin Machine

The seed cotton samples were ginned by using sawgin machine at laboratory of Field Crops Department of Agricultural Faculty of Adnan Menderes University in Aydin province.

\section{Properties Determined by Using HVI}

Fiber properties of the lint samples were determined by using HVI at laboratory of quality control of Narteks Textile mill. Fiber length (mm), fiber fineness (micronaire), fiber strength $\left(\mathrm{g} \mathrm{tex}^{-1}\right)$, uniformity index $(\%)$, short fiber index (\%) and spinning concistency index (SCI) were investigated by using HVI.

\section{Properties Determined by Using AFIS}

In spite of AFIS is not widespread as much as HVI, it provides especially important knowledge's about yarn lengths and distributions for yarn producers. While HVI measures bunch of fibers, AFIS measures fibers individually. More detailed length measures, dust, scraps, neps has been determined by AFIS. Fiber properties of the lint samples were determined by using AFIS at laboratory of Iskur Textile mill. Nep count (number $\mathrm{g}^{-1}$ ), nep size $(\mu \mathrm{m})$, total particule number (number $\left.\mathrm{g}^{-1}\right)$, mean particule size $(\mu \mathrm{m})$, dust particule number (number $\left.\mathrm{g}^{-1}\right)(<500 \mu \mathrm{m})$, trash count (number $\left.\mathrm{g}^{-1}\right)(>500 \mu \mathrm{m})$ were investigated by using AFIS.

\section{Statistical Method}

Obtained data were analysed according to factorial randomized block design by using SAS statistical package program. Means found statistically important were compared with each other by using the same program according to $\operatorname{LSD}_{(0,05)}$ (Least Significant Difference) multiple comparison test. 


\section{Results and Discussion}

\section{Ginning Outturn (\%)}

According to results of variance analyses it has been seen that the difference between ginning methods and cultivars were statistically significant (respectively at $\mathrm{P} \leq 0.01$ and $\mathrm{P} \leq 0.05$ ) for ginning outturn. Means of ginning outturn of cultivars, ginning methods and interactions of ginning methods $x$ cultivars and arised groups were given in Table 1. For ginning outturn there were differences between both ginning methods and cultivars (Table 1.). While ginning outturn mean of rollergin was $38.6 \%$ ginning outturn mean of sawgin was $37.2 \%$. It has been seen that means of ginning outturn of cultivars varied between $35.8 \%$ and $39.7 \%$. While the highest ginning outturns were taken from Erşan-92 and PG $2018 \mathrm{cv}$. the lowest ginning outturns were taken from Lydia, Maras-92, Flash and Carisma cv. It can be said that interactions of ginning methods $\times$ cultivars were not statistically significant because ginning outturns of all cultivars ginned rollergin were determined higher than ginning outturns of all cultivars ginned sawgin. Our results were similar to or less than ones reported by Karademir et al. (2018) (39.15$41.85 \%)$; Köken and İlker (2020) (37.3-45.0\%); Bednarz et al. (2005) (36.9-38.2\%); Çiçek et al. (2015) (43.70\%); Mizrak (2019) (36.63-47.03\%) and Balc1 (2018) (mean of lines and testers is $43.16 \%$ and mean of hybrids is $43.68 \%$ ) depending on varieties used, environmental conditions and cultivation practices. Delhom et al. (2017) also noted higher ginning outturn mean of rollergin system $(37.3 \%)$ than ginning outturn mean of sawgin system $(35 \%)$ similarly to our results. Porter et al. (2017) reported partly similar or lower ginning outturns in sawgin system for different sampling location teratments at harvesting (25.8$37.5 \%)$ and for cultivars (29.4-30.5\%). These differences may be caused by different varieties, climatic and soil conditions and different cultivation practices.

\section{Properties Determined by Using HVI}

\section{Fiber Length ( $\mathrm{mm})$}

For fiber length according to results of variance analyses it has been seen that the difference between ginning methods and cultivars were statistically significant (respectively at $\mathrm{P} \leq 0.05$ and $\mathrm{P} \leq 0.01$ ). Means of fiber length of cultivars, ginning methods and interactions of ginning methods $\times$ cultivars and arised groups were given in Table 1. From Table 1, while mean of fiber length obtained from rollergin was $30.21 \mathrm{~mm}$ those of sawgin was $29.78 \mathrm{~mm}$. From the same table, it can be realized that fiber lengths of cultivars varied between $30.87 \mathrm{~mm}$ and $29.41 \mathrm{~mm}$. The most fiber length was taken from Lydia followed by Carisma and the shorthest fibers were taken from Erşan-92. The all cultivars investigated were in "long" category for fiber length classification. Results obtained were similar to, less or more than ones noted by Karademir et al. (2018) (24.67-31.12 mm); Karademir et al. (2015) (26.97-30.19 mm); Köken and İlker (2020) (27.1-32.1 mm); Kaya et al. (2007) (27.9-28.6 mm); Bednarz et al. (2005) (27.1-28.2 mm); Boykin (2008) (26.8-28.5 mm); Çiçek et al. (2015) (32.08 mm); Balc1 (2018) (mean of lines and testers is $30.38 \mathrm{~mm}$ and mean of hybrids is $30.96 \mathrm{~mm}$ ) and Mizrak (2019) (28.18-32.02 mm) depending on varieties used, environmental conditions and cultivation practices.
Delhom et al. (2017) also noted higher fiber length mean of rollergin system $(31.5 \mathrm{~mm})$ than fiber length mean of sawgin system $(30.5 \mathrm{~mm})$ similarly to our results. Miao and Gordon (2020) reported similar results for fiber length in sawgin system (30.0 and $31.1 \mathrm{~mm})$.

\section{Fiber Fineness (micronaire)}

For fiber fineness according to results of variance analyses it has been found that the difference between ginning methods, cultivars and interactions of ginning methods $x$ cultivars were not statistically significant (Table 1). Means of fiber fineness of cultivars, ginning methods and interactions of ginning methods $\times$ cultivars and arised groups were given in Table 1. Mean of fiber fineness obtained from rollergin was 4.96 mic. and those of sawgin was 4.98 mic. The most finest fibers were obtained from BA119 (4.78 mic.) and Maraş-92 (4.80 mic.) and the most thickest fibers were obtained from Erşan-92 (5.17 mic.) and PG2018 (5.18 mic.). Carisma, BA 440, BA 119 and Maraş-92 cv. were in "middle" category, but Lydia, PG 2018, Flash and Erşan-92 cv. were in "thick" category for fiber fineness classification. Our results were parallel to ones reported by Karademir et al. (2018) (4.00-5.01 mic.); Karademir et al. (2015) (4.18-4.62 mic.); Boykin (2008) (4.12-4.96 mic.); Bednarz et al. (2005) (4.1-4.3 mic.); Köken and İlker (2020) (4.9-5.7 mic.); Mizrak (2019) (4.42-5.24 mic.), Kaya et al. (2007) (4.7-5.0 mic.); Balc1 (2018) (mean of lines and testers is 4.67 mic. and mean of hybrids is 4.69 mic.) and Çiçek et al. (2015) (4.84 mic.). Delhom et al. (2017) noted that there was not statistically significant difference between fiber fineness mean of rollergin system (3.95 mic.) and fiber fineness mean of sawgin system (3.85 mic.). Porter et al. (2017) reported lower fiber fineness values after saw ginning for different sampling location teratments at harvesting (4.2-4.4 mic.) and for cultivars (4.0-4.6 mic.).

Fiber Strength $\left(\mathrm{g}_{\text {tex }}{ }^{-1}\right)$

For fiber strength according to results of variance analyses it has been seen that the difference between ginning methods and cultivars were statistically significant $(\mathrm{P} \leq 0.01)$ (Table 1$)$. Means of fiber strength of cultivars, ginning methods and interactions of ginning methods $\times$ cultivars and arised groups were given in Table 1. According to Table 1. there has been a difference between fiber strengths obtained from rollergin and sawgin. Fiber strength of cultivars in rollergin system was higher $\left(31.76 \mathrm{~g} \mathrm{tex}^{-1}\right)$ than those in sawgin system $\left(30.97 \mathrm{~g}^{-} \mathrm{x}^{-}\right.$ ${ }^{1}$ ). The highest fiber strength were obtained from Lydia (32.56 $\left.\mathrm{g} \mathrm{tex}^{-1}\right)$, Flash (31.96 $\mathrm{g} \mathrm{tex}^{-1}$ ) and BA440 cv. (32.17 $\left.\mathrm{g} \mathrm{tex}^{-1}\right)$. The lowest fiber strength also were taken from Carisma (30.60 $\mathrm{g} \mathrm{tex}^{-1}$ ) and PG2018 cv. (30.25 $\mathrm{g} \mathrm{tex}^{-1}$ ) (Table 1). While Carisma, PG 2018, BA 119 and Erşan-92 cv. take place in "good" category, Lydia, Flash, BA 440 and Maraş-92 has taken place in "very good" category for fiber strength clasification. Delhom et al. (2017) noted that there was not statistically significant difference between fiber strength mean of rollergin system $\left(29.1 \mathrm{~g} \mathrm{tex}^{-1}\right)$ and fiber strength mean of sawgin system (30.1 $\left.\mathrm{g} \mathrm{tex}^{-1}\right)$. Miao and Gordon (2020) (30.3$\left.31.8 \mathrm{~g} \mathrm{tex}^{-1}\right)$; Karademir et al. (2018) (28.45-33.75 $\left.\mathrm{g} \mathrm{tex}^{-1}\right)$; Boykin (2008) (26.24-32.71 $\left.\mathrm{g} \mathrm{tex}^{-1}\right)$; Köken and İlker (2020) (31.2-36.2 $\left.\mathrm{g} \mathrm{tex}^{-1}\right)$; Kaya et al. (2007) (29.3-31.1 $\left.\mathrm{g} \mathrm{tex}^{-1}\right)$; Çiçek et al. (2015) (37.1 $\left.\mathrm{g} \mathrm{tex}^{-1}\right)$; Karademir et al. (2015) (30.42-36.68 $\mathrm{g} \mathrm{tex}^{-1}$ ); Balc1 (2018) (mean of lines and testers 
is $32.44 \mathrm{~g} \mathrm{tex}^{-1}$ and mean of hybrids is $\left.32.96 \mathrm{~g} \mathrm{tex}^{-1}\right)$ and Mizrak (2019) (32.27 $\mathrm{g} \mathrm{tex}^{-1}$ ) noted similar, less or more values. Differences may result from varieties used, environmental conditions and cultivation practices. Porter et al. (2017) reported similar fiber strength values after saw ginning for different sampling location teratments at harvesting (30.7-31.5 $\left.\mathrm{g} \mathrm{tex}^{-1}\right)$ and for cultivars (30.8-31.2 $\mathrm{g}$ tex $^{-1}$ ).

\section{Uniformity Index (\%)}

For uniformity index according to results of variance analyses it has been seen that the difference between ginning methods were statistically significant $(\mathrm{P} \leq 0.01)$ (Table 1$)$. Means of uniformity index of cultivars, ginning methods and interactions of ginning methods $\times$ cultivars and arised groups were given in Table 1. It can be seen that there is a difference between uniformity index obtained from rollergin and sawgin. While uniformity index from rollergin is in "very good" category with $86.02 \%$, ones of sawgin is in "good" category with $84.61 \%$. The highest uniformity index was taken from Erşan-92 cv. with $86.02 \%$ and the lowest uniformity index were taken from PG2018 and Maraş-92 cv. with $85.08 \%$ and $85.06 \%$ respectively. Delhom et al. (2017) also noted higher uniformity index mean of rollergin system $(84.7 \%)$ than uniformity index means of sawgin system $(82.7 \%)$ similarly to our results. Karademir et al. (2018) (80.07-85.42\%); Bednarz et al. (2005) (80.9-82.3\%); Karademir et al. (2015) (81.25-86.43\%); Boykin (2008) (82.0-83.4\%); Köken and İlker (2020) (80.07-85.42\%) reported similar results. Porter et al. (2017) reported that this trait was not statistically significant and that lower uniformity indexes in sawgin system for different sampling location teratments at harvesting (80.63-80.91\%) and for cultivars $(80.79-80.80 \%)$.

\section{Short Fiber Index (\%)}

For short fiber index according to results of variance analyses it has been seen that the difference between ginning methods were statistically significant $(\mathrm{P} \leq 0.01)$. Means of short fiber index of cultivars, ginning methods and interactions of ginning methods $\mathrm{x}$ cultivars and arised groups were given in Table 1. From Table 1, it can be seen that short fiber index values in rollergin system $(3,47 \%)$ were lower than those in sawgin system $(4.38 \%)$. While both ginning methods has taken place in "very good" category to be obtained lower short fiber index in rollergin has shown that this system is high quality and suitable for yarn spinning. The lowest short fiber index was obtained from Erşan-92 cv. (3.48\%) and the highest short fiber indexes were taken from BA119 (4.28\%) and Maraş-92 cv. $(4.26 \%)$ (Table 1). The all cultivars investigated were in "very good" category for short fiber index. Delhom et al. (2017) also noted lower short fiber index mean of rollergin system $(6.8 \%)$ than short fiber index mean of sawgin system (8.6\%) similarly to our results. Copur et al. (2015), reported higher short fiber index values $(18.31-23.22 \%)$ in rollergin system. Researchers explained this difference with cultivars, years, harvesting and ginning conditions. Miao and Gordon (2020), Karademir et al. (2015), Boykin (2008) and Bednarz et al. (2005) noted higher short fiber index values than our results respectivelly $(7.8-8.9 \%$; $7.73-$ $9.86 \% ; 6.26-8.89 \%$ and $8.56-9.0 \%)$. Porter et al. (2017) reported higher short fiber indexes after saw ginning for different sampling location teratments at harvesting (11.04-12.39\%) and for cultivars (11.07-12.05\%).

\section{Spinning Consistency Index (SCI)}

For spinning consistency index according to results of variance analyses it has been seen that the difference between ginning methods were statistically significant $(\mathrm{P} \leq 0.01)$. Means of spinning consistency index of cultivars, ginning methods and interactions of ginning methods $x$ cultivars and arised groups were given in Table 1. From table, it can be seen that spinning consistency index in rollergin system was higher (104.68) than those in sawgin system (94.50). Spinning consistency indexes of cultivars varied between 93.75 and 104.25. Lydia, Flash, BA440 and Maraş-92 cv. had the highest values for spinning consistency index. PG2018 cv. had also the lowest value for this character (Table 1). Çiçek et al. (2015) (107.50) reported similar results. But Hughs and Lalor (1990) reported that ginning with rollergin does not have important effect on yarn spinning.

\section{Properties Determined by Using AFIS}

Means of cultivars, ginning methods and interactions of ginning methods $\times$ cultivars and arised groups for properties by using AFIS were given in Table 2 .

\section{Nep Count (Number $g^{-1}$ )}

For nep count according to results of variance analyses it has been seen that the difference between ginning methods were statistically significant $(\mathrm{P} \leq 0.01)$. Means of nep count of cultivars, ginning methods and interactions of ginning methods $\times$ cultivars and arised groups were given in Table 2. While nep count means in rollergin system were 59.40 number $\mathrm{g}^{-1}$ those in sawgin system were 119.34 number $\mathrm{g}^{-1}$. From the same table it can be seen that nep counts of cultivars varied between 77.00 and 103.00 number $\mathrm{g}^{-1}$. It has been relized that sawgin system caused more nep count than rollergin system. Rollergin has taken place in "very little" nep category and sawgin has taken place in "little" nep category. On the contrary Delhom et al. (2017) noted that there was not statistically significant difference between nep count mean of rollergin system (231 number $\left.\mathrm{g}^{-1}\right)$ and nep count mean of sawgin system (309 number $\left.\mathrm{g}^{-1}\right)$. K1ll1 and Tekinşen (2007) noted higher nep counts in rollergin system 44.75 number $0.5 \mathrm{~g}^{-1}$ at $7 \%$ moisture content and 54.58 number $0.5 \mathrm{~g}^{-1}$ at $9 \%$ moisture content. These differences may be caused that varieties from G. barbadense besides of G. hirsutum were also used in trial. Similarly, Hughs et al. (1998) noted that nep counts in fabrics pruduced using yarn from sawgin cottons ( 23.4 neps $58 \mathrm{~cm}^{2-1}$ ) were higher than ones in fabrics pruduced using yarn from rollergin cottons (17.1 neps $\left.58 \mathrm{~cm}^{2-1}\right)$. Boykin (2008) noted higher nep counts in sawgin system (140-292 number $\left.\mathrm{g}^{-1}\right)$. Balc1 (2018) noted similar total nep count (mean of lines and testers is 44.2 number $\mathrm{g}^{-1}$ and mean of hybrids is 58.4 number $\mathrm{g}^{-1}$ ) in rollergin system. Ünay et al. (2019) reported lower nep count (mean of lines and testers is 38.5 number $\mathrm{g}^{-1}$; mean of hybrids is 46.75 number $\mathrm{g}^{-1}$ ) in rollergin system. Çopur et al. (2015) reported that nep counts obtained from rollergin system were 53.33-107 number $\mathrm{g}^{-1}$. Porter et al. (2017) reported higher nep count in sawgin system for different sampling location teratments at harvesting (271.6-374.3 number $\mathrm{g}^{-1}$ ) and for cultivars (257.7-353.0 number $\left.\mathrm{g}^{-1}\right)$. These differences may be caused by different varieties, climatic and soil conditions and different cultivation practices. Lower nep count has advantages in terms of facility of both seed cotton and lint cotton cleaning. 
Table 1. Means of cultivars, ginning methods and interactions of ginning methods $\times$ cultivars and arised groups for properties determined by using HVI

\begin{tabular}{|c|c|c|c|c|c|c|c|c|c|}
\hline \multicolumn{10}{|c|}{ Ginning outturn (\%) } \\
\hline Cultivars & Lydia & Carisma & PG2018 & Flash & BA440 & BA119 & Maraş-92 & Erşan-92 & Means \\
\hline Rollergin & 37.8 & 38.6 & 39.5 & 38.5 & 38.9 & 39.2 & 37.5 & 39.2 & $38.6^{\mathrm{a}}$ \\
\hline Sawgin & 36.6 & 35.5 & 38.5 & 35.8 & 37.6 & 37.4 & 36.9 & 39.7 & $37.2^{\mathrm{b}}$ \\
\hline Means & $37.2^{\mathrm{b}}$ & $37.0^{\mathrm{b}}$ & $39.0^{\mathrm{a}}$ & $37.1^{\mathrm{b}}$ & $38.2^{\mathrm{ab}}$ & $38.3^{\mathrm{ab}}$ & $37.2^{\mathrm{b}}$ & $39.4^{\mathrm{a}}$ & \\
\hline \multicolumn{10}{|c|}{ Fiber Lenght $(\mathrm{mm})$} \\
\hline Cultivars & Lydia & Carisma & PG2018 & Flash & BA440 & BA119 & Maraş-92 & Erşan-92 & Means \\
\hline Rollergin & 31.44 & 30.61 & 30.61 & 29.93 & 29.65 & 29.91 & 29.96 & 29.59 & $30.21^{\mathrm{a}}$ \\
\hline Sawgin & 30.30 & 29.78 & 29.67 & 30.35 & 29.63 & 29.37 & 29.88 & 29.23 & $29.78^{b}$ \\
\hline Means & $30.87^{\mathrm{a}}$ & $30.19^{\mathrm{ab}}$ & $30.14^{\mathrm{b}}$ & $30.14^{\mathrm{b}}$ & $29.64^{\mathrm{bc}}$ & $29.64^{\mathrm{bc}}$ & $29.92^{\mathrm{bc}}$ & $29.41^{\mathrm{c}}$ & \\
\hline \multicolumn{10}{|c|}{ Fiber Fineness (mic.) } \\
\hline Cultivars & Lydia & Carisma & PG2018 & Flash & BA440 & BA119 & Maraş-92 & Erşan-92 & Means \\
\hline Rollergin & 4.98 & 4.85 & 5.18 & 5.12 & 4.79 & 4.83 & 4.77 & 5.18 & 4.96 \\
\hline Sawgin & 5.07 & 4.91 & 5.18 & 5.06 & 4.96 & 4.72 & 4.83 & 5.15 & 4.98 \\
\hline Means & $5.02^{\mathrm{ab}}$ & $4.88^{\mathrm{ab}}$ & $5.18^{\mathrm{b}}$ & $5.09^{\mathrm{ab}}$ & $4.88^{\mathrm{ab}}$ & $4.78^{\mathrm{a}}$ & $4.80^{\mathrm{a}}$ & $5.17^{\mathrm{b}}$ & \\
\hline \multicolumn{10}{|c|}{ Fiber Strenght $\left(\mathrm{g}\right.$ tex $\left.{ }^{-1}\right)$} \\
\hline Cultivars & Lydia & Carisma & PG2018 & Flash & BA440 & BA119 & Maraş-92 & Erşan-92 & Means \\
\hline Rollergin & 33.00 & 30.67 & 30.90 & 32.80 & 32.77 & 30.95 & 32.20 & 30.85 & $31.76^{\mathrm{a}}$ \\
\hline Sawgin & 32.12 & 30.52 & 29.60 & 31.12 & 31.57 & 30.72 & 31.40 & 30.72 & $30.97^{\mathrm{b}}$ \\
\hline Means & $32.56^{\mathrm{a}}$ & $30.60^{c}$ & $30.25^{\mathrm{c}}$ & $31.96^{\mathrm{a}}$ & $32.17^{\mathrm{a}}$ & $30.83^{\mathrm{bc}}$ & $31.80^{\mathrm{ab}}$ & $30.78^{\mathrm{bc}}$ & \\
\hline \multicolumn{10}{|c|}{ Uniformity index (\%) } \\
\hline Cultivars & Lydia & Carisma & PG2018 & Flash & BA440 & BA119 & Maraş-92 & Erşan-92 & Means \\
\hline Rollergin & 85.80 & 86.00 & 85.92 & 85.95 & 85.60 & 86.30 & 85.90 & 86.72 & $86.02^{\mathrm{a}}$ \\
\hline Sawgin & 84.82 & 84.50 & 85.25 & 84.85 & 84.87 & 84.07 & 84.22 & 85.32 & $84.61^{\mathrm{b}}$ \\
\hline Means & $85.31^{\mathrm{ab}}$ & $85.25^{\mathrm{ab}}$ & $85.08^{\mathrm{b}}$ & $85.40^{\mathrm{ab}}$ & $85.23^{\mathrm{ab}}$ & $85.18^{\mathrm{ab}}$ & $85.06^{\mathrm{b}}$ & $86.02^{\mathrm{a}}$ & \\
\hline \multicolumn{10}{|c|}{ Short Fiber Index $(\%)$} \\
\hline Cultivars & Lydia & Carisma & PG2018 & Flash & BA440 & BA119 & Maraş-92 & Erşan-92 & Means \\
\hline Rollergin & 3.42 & 3.42 & 3.47 & 3.45 & 3.55 & 3.42 & 3.65 & 3.42 & $3.47^{\mathrm{a}}$ \\
\hline Sawgin & 4.02 & 4.27 & 4.70 & 4.32 & 4.17 & 5.15 & 4.87 & 3.55 & $4.38^{\mathrm{b}}$ \\
\hline Means & $3.72^{\mathrm{ab}}$ & $3.85^{\mathrm{ab}}$ & $4.08^{\mathrm{ab}}$ & $3.88^{\mathrm{ab}}$ & $3.86^{\mathrm{ab}}$ & $4.28^{\mathrm{b}}$ & $4.26^{\mathrm{b}}$ & $3.48^{\mathrm{a}}$ & \\
\hline \multicolumn{10}{|c|}{ Spinning Consistency index (SCI) } \\
\hline Cultivars & Lydia & Carisma & PG2018 & Flash & BA440 & BA119 & Maraş-92 & Erşan-92 & Means \\
\hline Rollergin & 109.50 & 103.25 & 100.50 & 105.25 & 106.00 & 104.50 & 106.50 & 102.00 & $104.68^{\mathrm{a}}$ \\
\hline Sawgin & 99.00 & 93.50 & 87.00 & 96.50 & 97.50 & 92.50 & 95.25 & 94.75 & $94.50^{\mathrm{b}}$ \\
\hline Means & $104.25^{\mathrm{a}}$ & $98.37^{\mathrm{ab}}$ & $93.75^{\mathrm{b}}$ & $100.87^{\mathrm{a}}$ & $101.75^{\mathrm{a}}$ & $98.50^{\mathrm{ab}}$ & $100.87^{\mathrm{a}}$ & $98.37^{\mathrm{ab}}$ & \\
\hline
\end{tabular}

\section{Nep Size $(\mu m)$}

For nep size according to results of variance analyses it has been seen that the difference between ginning methods and cultivars were statistically significant (respectively at $\mathrm{P} \leq 0.01$ and $\mathrm{P} \leq 0.05$ ). Means of nep size of cultivars, ginning methods and interactions of ginning methods $\mathrm{x}$ cultivars and arised groups were given in Table 2 . While nep size mean in rollergin system were $751.06 \mu \mathrm{m}$ those in sawgin system were $674.50 \mu \mathrm{m}$. It has been seen that nep size values of cultivars varied between $675.63 \mu \mathrm{m}$ and $765.38 \mu \mathrm{m}$ and Lydia and PG $2018 \mathrm{cv}$. had the lowest nep sizes but Flash cv. had the highest nep size (Table 2.). Nep size both in seed cotton and in lint cotton is required high by ginners because higher nep size has advantages in terms of facility of cleaning. Balc1 (2018) noted similar total nep size (mean of lines and testers is 739.1 number $\mathrm{g}^{-1}$ and mean of hybrids is 769.8 number $\mathrm{g}^{-1}$ ). Ünay et al. (2019) reported lower neps size (means of lines and testers 683.1 $\mu \mathrm{m}$; means of hybrids $651.7 \mu \mathrm{m})$ in rollergin system. This difference can be caused due to genotypes used as material in trials, cultural applications or environments. Boykin (2008) noted similar nep sizes in sawgin system (669-710 $\mu \mathrm{m})$.
Total Particule Number (Number $G^{-1}$ )

For total particule number according to results of variance analyses it has been found that the differences between ginning methods, cultivars and interactions of ginning methods $\mathrm{x}$ cultivars were not statistically significant. It is required that variation coefficient $(\mathrm{CV})$ is not higher than $33 \%$. However, CV value was calculated higher because total particule numbers of samples were great variable. Means of total particule number of cultivars, ginning methods and interactions of ginning methods $\mathrm{x}$ cultivars and arised groups were given in Table 2. Mean of total particul number obtained from rollergin system was 341.19 number $\mathrm{g}^{-1}$ and those of sawgin system was 366.44 number $\mathrm{g}^{-1}$. While Erşan-92 cv. had the lowest total particule number (231.4 number $\mathrm{g}^{-1}$ ) Flash $\mathrm{cv}$. had the highest total particule number (490.6 number $\mathrm{g}^{-1}$ ) (Table 2 ). Total particule number both in seed cotton and in lint cotton is required low by ginners in terms of cleaning.

Mean particule size $(\mu \mathrm{m})$

For mean particule size according to results of variance analyses it has been found that the differences between ginning methods, cultivars and interactions of ginning methods $\times$ cultivars were not statistically significant. 
Table 2. Means of cultivars, ginning methods and interactions of ginning methods $\times$ cultivars and arised groups for properties determined by using AFIS

\begin{tabular}{|c|c|c|c|c|c|c|c|c|c|}
\hline \multicolumn{10}{|c|}{ Nep count (number $\mathrm{g}^{-1}$ ) } \\
\hline Cultivars & Lydia & Carisma & PG2018 & Flash & BA440 & BA119 & Maraş-92 & Erşan-92 & Means \\
\hline Rollergin & 39.50 & 68.50 & 52.75 & 59.25 & 71.00 & 59.00 & 67.00 & 58.00 & $59.40^{\mathrm{a}}$ \\
\hline Sawgin & 114.50 & 130.75 & 108.50 & 105.50 & 125.75 & 122.50 & 139.00 & 108.25 & $119.34^{\mathrm{b}}$ \\
\hline Means & 77.00 & 99.63 & 80.63 & 82.38 & 98.38 & 90.75 & 103.00 & 83.25 & \\
\hline \multicolumn{10}{|c|}{ Nep size $(\mu \mathrm{m})$} \\
\hline Cultivars & Lydia & Carisma & PG2018 & Flash & BA440 & BA119 & Maraş-92 & Erşan-92 & Means \\
\hline ollergin & 701.50 & 749.50 & 691.50 & 812.75 & 733.25 & 724.50 & 805.25 & 790.25 & $751.06^{\mathrm{a}}$ \\
\hline awgin & 649.75 & 674.25 & 662.50 & 718.00 & 660.50 & 669.75 & 662.00 & 699.25 & $674.50^{\mathrm{b}}$ \\
\hline Means & $675.63^{\mathrm{c}}$ & $711.88^{\mathrm{abc}}$ & $677.00^{\mathrm{c}}$ & $765.38^{\mathrm{a}}$ & $696.88^{\mathrm{bc}}$ & $697.13^{\text {bc }}$ & $733.63^{\mathrm{ab}}$ & $744.75^{\mathrm{ab}}$ & \\
\hline \multicolumn{10}{|c|}{ Total particule number (number $\mathrm{g}^{-1}$ ) } \\
\hline ultivars & Lydia & Carisma & PG2018 & Flash & BA440 & BA119 & Maraş-92 & Erşan-92 & Means \\
\hline ollergin & 281.25 & 239.50 & 276.25 & 465.75 & 397.25 & 369.00 & 554.50 & 151.75 & 341.91 \\
\hline Sawgin & 432.25 & 383.50 & 542.50 & 515.50 & 222.00 & 190.00 & 334.75 & 311.00 & 366.44 \\
\hline Means & $356.8^{\mathrm{ab}}$ & $311.5^{\mathrm{ab}}$ & $409.4^{\mathrm{ab}}$ & $490.6^{\mathrm{b}}$ & $309.6^{\mathrm{ab}}$ & $279.5^{\mathrm{ab}}$ & $444.6^{\mathrm{ab}}$ & $231.4^{\mathrm{a}}$ & \\
\hline \multicolumn{10}{|c|}{ Mean particule size $(\mu \mathrm{m})$} \\
\hline ultivars & Lydia & Carisma & PG2018 & Flash & BA440 & BA119 & Maraş-92 & Erşan-92 & Means \\
\hline Rollergin & 260.25 & 286.50 & 256.50 & 253.75 & 258.25 & 265.50 & 246.25 & 265.00 & 261.50 \\
\hline Sawgin & 252.25 & 265.00 & 288.00 & 237.25 & 275.25 & 290.75 & 268.00 & 270.25 & 268.34 \\
\hline Means & $256.25^{\mathrm{ab}}$ & $275.75^{\mathrm{a}}$ & $272.25^{\mathrm{ab}}$ & $245.50^{\mathrm{b}}$ & $266.75^{\mathrm{ab}}$ & $278.13^{\mathrm{a}}$ & $257.13^{\mathrm{ab}}$ & $267.63^{\mathrm{ab}}$ & \\
\hline \multicolumn{10}{|c|}{ Dust particule number (number $\mathrm{g}^{-1}$ ) } \\
\hline Cultivars & Lydia & Carisma & PG2018 & Flash & BA440 & BA119 & Maraş-92 & Erşan-92 & Means \\
\hline Rollergin & 246.25 & 213.25 & 247.25 & 415.50 & 362.25 & 334.75 & 500.00 & 136.25 & 306.94 \\
\hline Sawgin & 386.50 & 344.75 & 476.25 & 472.25 & 194.25 & 162.75 & 292.25 & 276.25 & 325.66 \\
\hline Means & $316.4^{\mathrm{ab}}$ & $279.0^{\mathrm{ab}}$ & $361.4^{\mathrm{ab}}$ & $443.9^{\mathrm{b}}$ & $278.3^{\mathrm{ab}}$ & $248.8^{\mathrm{ab}}$ & $396.1^{\mathrm{ab}}$ & $206.3^{\mathrm{a}}$ & \\
\hline \multicolumn{10}{|c|}{ Trash count (number $\mathrm{g}^{-1}$ ) } \\
\hline Cultivars & Lydia & Carisma & PG2018 & Flash & BA440 & BA119 & Maraş-92 & Erşan-92 & Means \\
\hline Rollergin & 35.00 & 26.25 & 29.00 & 50.25 & 35.00 & 34.25 & 54.50 & 15.50 & 34.96 \\
\hline Sawgin & 45.50 & 38.75 & 66.25 & 43.25 & 27.75 & 27.25 & 42.50 & 34.75 & 40.75 \\
\hline Means & $40.25^{\mathrm{ab}}$ & $32.50^{\mathrm{ab}}$ & $47.63^{\mathrm{ab}}$ & $46.75^{\mathrm{ab}}$ & $31.38^{\mathrm{ab}}$ & $39.75^{\mathrm{ab}}$ & $48.50^{\mathrm{b}}$ & $25.13^{\mathrm{a}}$ & \\
\hline
\end{tabular}

Means of particule size of cultivars, ginning methods and interactions of ginning methods $\mathrm{x}$ cultivars and arised groups were given in Table 2. Mean particule size obtained from rollergin system was $261.50 \mu \mathrm{m}$ and those of sawgin system was $268.34 \mu \mathrm{m}$. Cultivars were statistically separeted into different groups fort this trait. While BA 119 $(278.13 \mu \mathrm{m})$ and Carisma cv. $(275.75 \mu \mathrm{m})$ had the most mean particule size Flash cv. $(245.50 \mu \mathrm{m})$ had the least mean particule size (Table 2). Higher mean particule size has advantages in terms of facility of both seed cotton and lint cotton cleaning.

\section{Dust Particule Number (Number $\left.\mathrm{g}^{-1}\right)(1500 \mu \mathrm{m})$}

For dust particule number according to results of variance analyses it has been found that the differences between ginning methods, cultivars and interactions of ginning methods $\mathrm{x}$ cultivars were not statistically significant. It is required that variation coefficient (CV) is not higher than $33 \%$. However, CV value was calculated higher because dust particule numbers of samples were great variable. Means of dust particule number of cultivars, ginning methods and interactions of ginning methods $\mathrm{x}$ cultivars and arised groups were given in Table 2. Mean of dust particul number obtained from rollergin system was 306.94 number $\mathrm{g}^{-1}$ and those of sawgin system was 325.66 number $\mathrm{g}^{-1}$. While Flash cv. had the most dust particule number (443.9 number $\mathrm{g}^{-1}$ ) Erşan-92 cv. had the least dust particule number (206.3 number $\mathrm{g}^{-1}$ ) (Table 2). Porter et al. (2017) reported similar dust particule number in sawgin system for different sampling location teratments at harvesting (108.9-403.6 number $\mathrm{g}^{-1}$ ) and for cultivars (277.6-314.8 number $\left.\mathrm{g}^{-1}\right)$. It has been required that dust particule number both in seed cotton and in lint cotton is less in terms of cleaning.

\section{Trash Count (Number ${ }^{-1}$ ) ( $(500 \mu \mathrm{m})$}

For trash count according to results of variance analyses it has been found that the differences between ginning methods, cultivars and interactions of ginning methods $\mathrm{x}$ cultivars were not statistically significant. It is required that variation coefficient $(\mathrm{CV})$ is not higher than $33 \%$. However, CV value was calculated higher because trash counts of samples were great variable. Means of trash count of cultivars, ginning methods and interactions of ginning methods $\mathrm{x}$ cultivars and arised groups were given in Table 2. Mean of trash count obtained from rollergin system was 34.96 number $\mathrm{g}^{-1}$ and those of sawgin system was 40.75 number $\mathrm{g}^{-1}$. Similarly, Delhom et al. (2017) noted that there was not statistically significant difference between trash count mean of rollergin system (103 number $\left.\mathrm{g}^{-1}\right)$ and trash count mean of sawgin system (100 number $\mathrm{g}^{-}$ ${ }^{1}$ ). But researchers determined higher trash counts than our results. Porter et al. (2017) reported lower, similar or higher trash count in sawgin system for different sampling location teratments at harvesting (23.3-96.1 number $\left.\mathrm{g}^{-1}\right)$ and for cultivars (60.8-79.0 number $\left.\mathrm{g}^{-1}\right)$. These differences may be caused by different varieties, climatic and soil conditions and different cultivation practices. Although there was not statistically difference between ginning methods for trash count, but significant differences among 
cultvars were determined statistically (Table 2.). While Erşan-92 cv. had the least trash count $\left(25.13\right.$ number $\left.\mathrm{g}^{-1}\right)$ Maraş-92 cv. had the most trash count (48.50 number $\mathrm{g}^{-1}$ ) (Table 2). The all means were in "less" category for trash count. Trash count both in seed cotton and in lint cotton is required low by ginners in terms of cleaning.

\section{Conclusions}

- In terms of ginning outturn, fiber length, uniformity index, fiber strength, spinning consistency index, short fiber index, nep count and nep size statistically significant differences were determined between ginning methods.

- In terms of ginning outturn, fiber length, fiber strength and nep size statistically significant differences were determined between cultivars.

- For all traits investigated interaction of ginning methods $x$ cultivars were not statistically significant.

- Mean of ginnig outturn, fiber length, fiber uniformity, fiber strength, spinning consistency index and short fiber index were higher in rollergin system than sawgin system.

- Mean of nep count was lower in rollergin system than sawgin system but mean of nep size was higher in rollergin system than sawgin system.

In conclusion it can be said that rollergin system has positively affected on ginning outturn, fiber length, uniformity index, fiber strength, spinning consistency index, short fiber index, nep count and nep size. It was determined that the best cultivar is Lydia in terms of fiber length, fiber strength, uniformity index, spinning consistency index and nep size; that the best cultivar is Erşan-92 in terms of ginning outturn, uniformity index, short fiber index, total particule number, dust particule number and trash count; and that the best cultivars are BA 119 and Maraş-92 in terms of fiber fineness for Kahramanmaraş province which is placed in east Mediterranean region of Turkey.

\section{References}

Anonymous 2006. Cotton Yarn Manufacturing. Textile Technologies, The Project of Improvement of System of Professional Education. MEGEP, Ankara-Turkey, 71 p.

Balc1 Ş. 2018. A Research on The Heredity of Agricultural and Technological Characteristics of Some Hybrid Cotton (Gossypium hirsutum L.) Populations in $\mathrm{F}_{1}$ Generations. Ph.D. Dissertation, Science Institute of Adnan Menderes University, Aydın-Turkey, 140 pages.

Bednarz CW, Shurley WD, Antony WS, Nicols RL. 2005. Yield, Quality and Profitability of Cotton Produced at Varying Plant Densities. Agronomy Journal 97: 235-240.

Boykin JC. 2008. Seed Coat Fragments, Motes, and Neps: Cultivar Differences. The Journal of Cotton Science, 12: 109125.

Chapman WE, Stedronsky VL. 1965. Comperative Performance of Saw and Rollergins on Acala and Pima Cottons. USDA, Agricultural Research Service, Marketing Research Report. No: 695.
Çiçek S, Yazıcı L, Çoban M, Küçüktaban F, Harem E. 2015. Studies of Conservation Breeding in Some Cotton (Gossypium hirsutum L.) Cultivars. National $11^{\text {th }}$ Field Crops Congress, 7-10 September 2015, Çanakkale-Turkey, Proceedings (2): 438-441.

Çopur O, Yuka A, Haliloğlu H, Bilgiç C. 2015. Determination of Nep Number and Some Seed and Fiber Characteristics of Cotton (Gossypium hirsutum L.) under Semi-Arid Conditions. National $11^{\text {th }}$ Field Crops Congress, 7-10 September 2015, Çanakkale-Turkey, Proceedings (2): 423426.

Delhom CD, Armijo CB, Hughs SE. 2017. High Quality Yarns Produced via High-Speed Roller ginning of Upland Cotton. The Journal of Cotton Science 21: 81-83.

Hughs SE, Lalor WF. 1990. Fiber and Yarn Effects of Roller Versus Saw Ginning. Proceeding of Beltwide Cotton Conference, USA, p: 542-543.

Karademir E, Karademir Ç, Ekinci R, Sevilmiş U. 2015. Determination of Yield and Lint Quality in Advanced Cotton (Gossypium hirsutum L.) Lines. Turkish Journal of Agricultural Research 2 (2): 100-107.

Karademir E, Karademir Ç, Sevilmiş U. 2018. Determination of Yield and Quality Characters of Advanced Cotton Lines under Conditions of Mardin Province of Turkey. Anatolia I ${ }^{\text {sth }}$ International Multidisipliner Studies Congress. Proceedings, ISBN 978-605-69046-0-8: 979-984.

Kaya H, Dolançay A, Toklu P, Türkoğlu ŞR, Nasırcı Z, Süllü S, Özbek BS. 2007. General Situation of Ginning Mills in Adana, Hatay, Gaziantep and Kahramanmaraş Peovinces, Quality Expectations for Seed Cotton, Problems and Suggestions of Solution. Publications of Directorate of Çukurova Agricultural Research Institute, Adana-Turkey.

K1llı F, Tekinşen F. 2007. Effects of Ginning on Short Fiber Index, Seed Coat Fragments, Neps and Mote Number in Different Moistured Cottons. National VII ${ }^{\text {th }}$ Field Crops Congress, 25-27 June 2007 Erzurum-Turkey, Proceedings: 2, 458-461.

Köken İ, İlker E. 2020. Determination of Yield and Quality Properties of Suitable Cotton Varieties for Aegean Region. Adnan Menderes University Journal of Agriculture, 2020; 17 (1):15-20.

Mizrak R. 2019. Investigation of Yield and Lint Quality Traits of Some Cotton Genotypes (Gossypium hirsutum L.) under Ecological Conditions of Diyarbakır. MSc Dissertation, Science Institute of Dicle University, Diyarbakır-Turkey.

Miao M, Gordon S. 2020. The Effect of Round Module Storage Time and Ambient Conditions on Cotton Quality. The Journal of Cotton Science 24: 211-228.

Oğlakc1 M. 2012. Plant Structure, Cultivation, Breeding and Lint Technology of Cotton Crop, ISBN: 978-605-464-922-8, Ankara-Turkey, $485 \mathrm{p}$.

Özel E. 2015. Examination of Ginneries, Linter and Pressing Mills in Turkey. M.Sc. Dissertation, Science Institute of Kahramanmaraş Sütçü İmam University, KahramanmarasTurkey, 102 pages.

Porter WM, Wanjura JD, Taylor RK, Boman RK, Buser MD. 2017. Tracking Cotton Fiber Quality and Foreign Matter through a Stripper Harvester. The Journal of Cotton Science 21: 29-39.

Tümer H. 2010. Effects of Ginning Methods on Lint Quality. M.Sc. Dissertation, Science Institute of Cukurova University, Adana-Turkey, 64 pages.

Ünay A, Balcı Ş, Çınar VM. 2019. Gene Action and Combining ability for Neps and Seed Coat Neps in Cotton. Turkish Journal of Field Crops, 24 (2): 211-214. 